\title{
Analysis of the Quality of Strategic Marketing Planning in Trading Companies in Bosnia and Herzegovina
}

\author{
Beriz Čivić ${ }^{1}$ \\ ${ }^{1}$ Faculty of Economics, University of Tuzla, Tuzla, Bosnia and Herzegovina \\ Correspondence: Beriz Čivić, Faculty of Economics, University of Tuzla, Univerzitetska 8 Street, 75000 Tuzla, \\ Bosnia and Herzegovina. Tel: 387-35-320-820 or 387-61-234-214. E-mail: beriz.civic@untz.ba
}

Received: March 23, 2013

Accepted: April 27, 2013

Online Published: May 17, 2013

doi:10.5539/ibr.v6n6p105

URL: http://dx.doi.org/10.5539/ibr.v6n6p105

\begin{abstract}
The main aim of this paper is the analysis of features of strategic marketing planning and the assessment of the quality of this process in business practice of trading companies in Bosnia and Herzegovina (BiH). The method used in assessing the quality of the creation of marketing plans in trading companies was the multivariate analysis (method of discriminant analysis). Among other things it has been established that marketing management of trading companies does not create marketing strategies on a formalized and systematic basis. It has also been established that the possibilities for improving business profitability and timely perception of the occurrence of unexpected business processes are the two determinants that have the strongest effect on marketing managers in trading companies and their preparedness to formalize their process of strategic marketing planning and establish it on a systematic approach.
\end{abstract}

Keywords: marketing strategy, planning, trading companies

\section{Introduction}

Regardless of the complexity of their business environment, certain companies at a given moment have better reactions to market challenges, when compared to their competitors. The thing that represents the source of the companies' successfulness and enables them to be more successful than others is the appropriate business strategy. Bearing in mind the key role which marketing decisions have in the development of market position and total business performances of the company, one can understand the need for focusing the modern management on providing the company's appropriate marketing strategies. In order to successfully manage business processes under modern business conditions, the management must link marketing and strategy as the basis for determining long-term goals, setting the guideline for the actions by which the company is led from the present to the future desired position, and defining the framework for involving resources necessary for achieving the desired business performances.

Namely, company's marketing activities should be, on the one hand, based strategically, but on the other hand, the company's business strategy needs to be led by the market and customers' needs with appreciating competition activities and lines coming from the macro-economic environment.

The process of outlining marketing strategy, its development and implementation are by no means an easy task. Marketing managers as well as marketing experts and other participants in the development of marketing strategy face numerous problems. Some of them are: need for a significant hiring of specialized know-how in different segments of marketing activities, immense activities on organization and realization of constant generating informational basis for marketing decision making, and significant costs in time and money. However, regardless of these elements, success under modern business conditions cannot be imagined without strategic marketing considerations and activities.

\section{Literature Overview}

Depending on its organizational structure, a company needs to develop corporative marketing strategy (which is relevant for the entire company), but it is necessary to lower the development of marketing strategy to the level of strategic business units (certainly, provided that the company organized its business process in such a way). Marketing strategies that are developed at a corporate level and the level of strategic business units do not differentiate in fundamental principles on which they are based since individual marketing strategies on the level 
of strategic business units should entirely correspond to the corporate marketing strategy. This is actually the case of the same basis of marketing strategy that is implemented at two organizational levels. This actually means that all the stages of creating marketing strategy, meaning all the stages of strategic marketing planning, should be implemented on both organization levels: from vision, mission and business goals, over the analysis of internal and external determinants, to the selection of appropriate strategic activities.

Kotler (2001) defines marketing strategy as market oriented strategic planning which is a managerial process of developing and keeping links between organization goals, sources, and skills, and the changeable market possibilities. The goals of strategic planning are designing and re-designing companies' business activities or their products and services in such a way that companies make the planned profit and growth. In brief, marketing strategy is a series of related actions that lead to a sustainable competitive advantage. Renko (2005) states some of the most important definitions of marketing strategy:

1) Marketing strategy is a fundamental framework of present and planned goals, resources, and interactions of the company with markets, competitors and other environment factors (Hollensen, 2003);

2) Marketing strategy is a fundamental framework which includes present and planned goals, exploiting company's resources, and the interaction of the company with markets, competitors, and other environment factors (Walker, Boyd \& Larreche, 1996);

3) Marketing strategy is setting the business goals and purpose of strategic business units, as well as the resources by which that will be achieved (Baker, 2000).

In the process of creating marketing strategy of trading companies, marketing managers need to obey the principles and process that are effective in strategic planning in general. However, when defining the content of certain marketing decisions and activities that are to be implemented, it is necessary to take into consideration the specific features of marketing processes characteristic of trading companies.

The basic specific features of activities of trading companies are determined by the position of trade in the reproduction cycle. Namely, trade is a service, primarily work intensive activity and it is a mediator between manufacture and consumption. It is important for trade to keep its openness towards its environment so that the role of a mediator between the two sides (manufacture and consumption) could be realized in a high-quality way. Creation of appropriate marketing instruments is a constant challenge to marketing managers in companies. In trading companies there are certain specific features that need to be perceived. They are primarily related to marketing instruments and the creation of their content. These specific features are especially evident in trading companies in the retail segment. Besides the elements of marketing mix, that also need to be in mind, while creating marketing operations in trading companies it is necessary to pay attention to a set of other factors out of which the following should be emphasized (adapted, Omar, 1999):

1) retail outlet location,

2) retail outlet atmosphere,

3) accompanying programs of retail outlet,

4) readiness to help at a retail outlet,

5) communication with customers,

6) personal sale,

7) sales person image,

8) encouraging sales processes.

In the practice of trading companies certain orientations have been given a more definite shape. They are used by traders in order to differentiate themselves from their competition and to make their position on the market, by applying different combinations of specific instruments such as: price level, turnover coefficient, service level, etc. In order to explain the content of these orientations, authors often use certain models such as the matrix of profit margin and turnover coefficient and the matrix of profit margin and service level thus explaining traders' marketing strategies (for details see: Lovreta \& Petković, 2010).

However, as a specific paradigm for marketing managers in the trading branch is certainly the "boom" made on the global retail sale market by Wal-Mart. What is interesting in the strengthening of the market position and growth of market share of this trading "giant" is the fact that in this case the seemingly incompatible relations were reconciled, meaning the higher level of service is provided for the lower price. It was usually considered that the level of price and service are directly proportional, i.e. the traders that offer lower prices provide the 
lower level of service and vice versa. Wal-Mart's successful practice shows that it is possible to build the profitability based strategy that will allow better level of service at lower prices and in that way harmonize these two important determinants of market positioning of trading companies.

It is evident that marketing in general, especially trade marketing, due to the direct contact trading companies with customers, has one of the key roles in creating new trends and determining development lines of many processes. Therefore, innovativeness and creativity are the necessary elements of creating and planning strategic marketing processes in trading companies. It is a creative process, by no means a stereotype procedure. Certainly, one must respect certain procedures that are characteristic of strategic planning, but defining the content of marketing activities is primarily innovative and creative work.

\section{Research Methodology}

Aim of the research: To establish the key features and evaluate the quality of the process of strategic marketing planning in trading companies in $\mathrm{BiH}$.

\section{Research hypotheses:}

$\mathrm{H}_{1}$ - The process of strategic marketing planning in the business practice of trading companies in $\mathrm{BiH}$ is not based on systematic and strategic principles;

$\mathrm{H}_{2}$ - Formalization of the process and the systematic approach to the creation of marketing strategy have a significant influence on the quality of marketing plans.

Data collection: The data presented in the following part of the paper are the result of the primary research (field research) and they are collected by the survey method (technique of written structural survey, the data collection form being a questionnaire). The data was collected from a sample of 60 subjects (trading companies) selected by the principle of randomly sampled. The questionnaire was filled in by top marketing managers in trading companies. The referential framework for the selection of sample units included the data from the register of the Indirect Taxation Authority of Bosnia and Herzegovina (ITA). This institution, along with the Agency for Statistics of Bosnia and Herzegovina, has the data on all the business subjects in $\mathrm{BiH}$. A total number of companies in the ITA register on January 31, 2010 was 199,865. The three-step screening was used as follows: first, inactive companies were eliminated; then the companies in which trade is the primary activity were selected (more than $50 \%$ of the revenue in the structure of total revenue is realized in trade); finally, trading companies with 20 or more employees were selected to represent a sample. Selection fraction of $6.5 \%$ assured that the sample belongs to the category of large samples. Data collection started at the end of February 2010, and it was over in mid November 2010 . The rejection level was $25 \%$. The collected data was first entered in the excel tables, and later imported into SPSS Statistics 19.0 for the discriminant analysis.

\section{Result Analysis and Discussion}

Variables analyzed in the paper are features of the process of strategic marketing planning and they represent an independent variable (the indicators for measuring an independent variable are given in Figure 1). On the other hand, the dependent variable which is analyzed is the effect/output of the process of strategic marketing planning (the indicators used for measuring the dependent variable are given in Table 1 and Figure 2). The method of the evaluation of the marketing planning process is outlined by the method which McDonald (2004) presented in his book Marketing plans-How to Prepare Them, How to Use Them, with certain adaption to the specificities of the trading companies' business activities.

\subsection{Features of Strategic Marketing Planning in Trading Companies in Bosnia and Herzegovina}

Business practice of trading companies in $\mathrm{BiH}$ is characterized, among other things, the lack of the key determinants of the strategic marketing planning process. The illustration of the condition of marketing planning by observed features in the practice of trading companies in $\mathrm{BiH}$ is presented in Figure 1. For example, data collection on strengths and weaknesses that exist within companies, as well as on the conditions and threats from the environment, followed by their analysis are poorly represented in the practice of trading companies in $\mathrm{BiH}$. In other words, out of the total number of the subjects, the collection and analysis of the mentioned data is present in only $27.12 \%$ of the trading companies surveyed. On the other hand, it is important to mention that these elements present, among other things, the foundation of strategic marketing planning.

By observing only the subjects answering that their companies collect and analyze the data on strengths and weaknesses within the company, as well as on the opportunities and threats in the surrounding, all of them emphasized that the analyses made in this way have an influence on the decision making process. Through an informal discussion with the decision makers, it has been established that such analyses have a significant role in 
the process of generating decisions and reducing risk. By observing further the same segment of subjects, it has been established that in a smaller number of trading companies $(6.25 \%)$ such analyses are seen as an attack on a certain sector within the company and/or someone's personal interest, not only as an attempt to promote business.

A large portion of the total number of marketing managers of trading companies surveyed (61.67\%) believes that their marketing goals are neither clearly determined nor harmonized with the total business goals of the company. It is a rather concerning fact that only one third of the total number of trading companies surveyed have a clear strategy for achieving marketing goals. Also, only 50.0\% of the total marketing managers surveyed believe that authorizations and responsibilities in achieving marketing goals in their companies are not clearly delegated, while $1.67 \%$ of the total number of subjects could not state their opinion on this issue. A relatively high level of $75.0 \%$ of all the subjects state that there is consent between individual management levels on the set marketing goals. On the other hand, the presence of control mechanisms which assure the realization of the planned marketing goals is not at an enviable level since only $41.67 \%$ of the trading companies have the mechanism of evaluation of marketing goals of business.

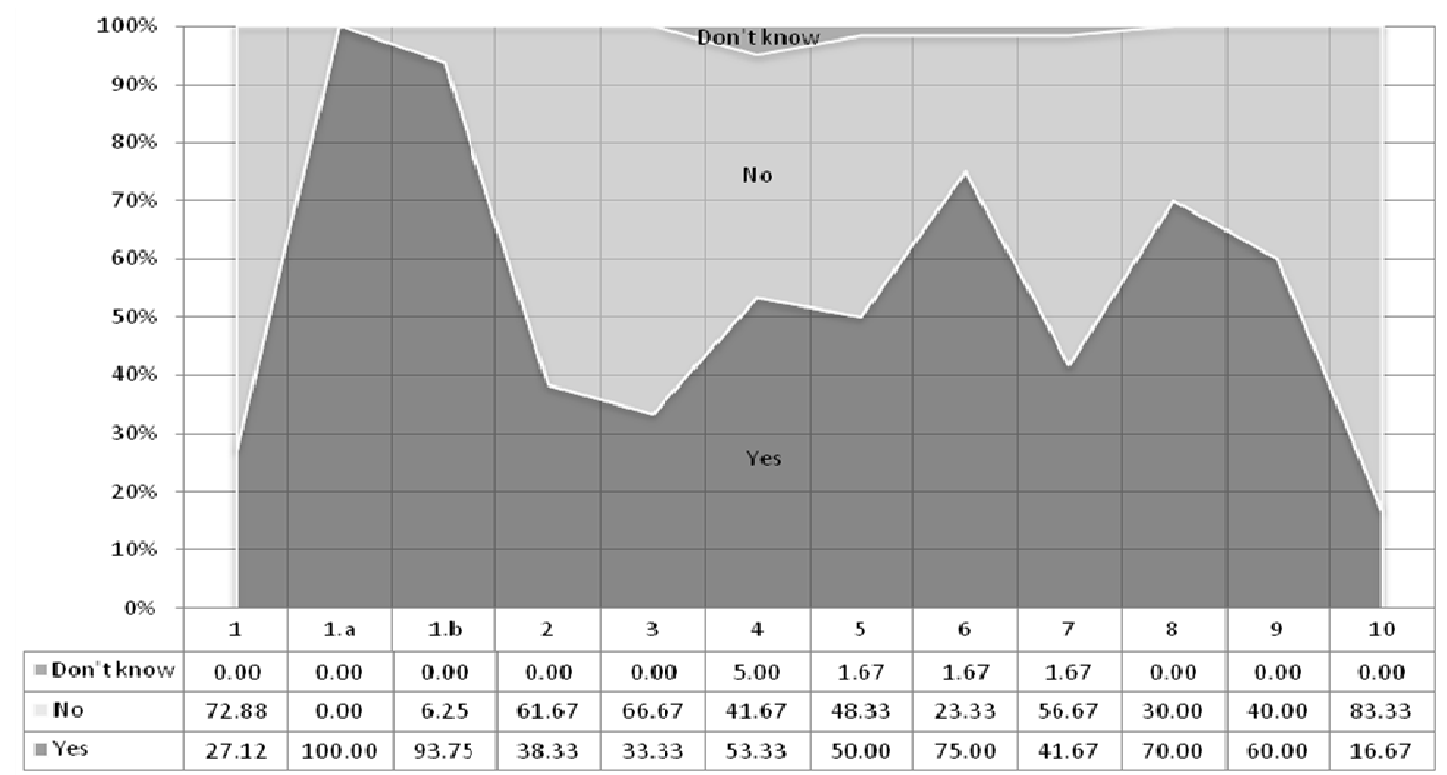

Figure 1. Features of strategic marketing planning in trading companies in $\mathrm{BiH}$ (Author's research) Legend:

1. Is there any person in your company who is in charge of collecting and analyzing data on strengths and weaknesses that exist within the company as well as on the opportunities and threats from the environment?

1a. Does their analysis have an effect in decision making (only the subjects who responded "Yes" to question 1)?

1b. Is the atmosphere in the company such that the total and accurate analysis is considered as an attempt to promote business, not as an attack on a certain sector or someone's personal interests (only the subjects who responded "Yes" to question 1)?

2. Are the marketing goals clearly determined and harmonized with the total business goals of the company?

3. Are there clear strategies for achieving these marketing goals?

4. Are there enough resources for the realization of the set goals?

5. Are the authorizations and responsibilities in achieving marketing goals clearly delegated?

6. Is there consent in the company between all the levels of management regarding the set marketing goals?

7. Are there control mechanisms in your company which provide the realization of the planned marketing goals?

8. Does the internal communication in your company function successfully?

9. Are there problems and difficulties in communication between marketing and other sectors (departments) in the company?

10. Is there a back-up plan in case the set marketing goals are not fulfilled?

The subjects emphasized that there are significant problems and difficulties in communication between marketing and other sectors (departments) in the company. Out of the total number of subjects, $60.0 \%$ of the trading companies emphasized this problem. The meaning of planning is, among other things, to prepare the company to act in critical situations. This element largely reflects the successfulness of the total planning, 
especially of the segment of marketing planning. The situation related to this issue is extremely bad in the trading companies in $\mathrm{BiH}$. Namely, only $16.67 \%$ of the total number of the trading companies surveyed has a back-up plan in case the set marketing goals are not fulfilled.

\subsection{Evaluation of the Quality of the Strategic Marketing Planning Process in Trading Companies in Bosnia and Herzegovina}

By observing all the subjects, it can be concluded that marketing managers of trading companies in $\mathrm{BiH}$ are significantly divided when it comes to the question whether their approach to marketing planning assures that they have a high level of harmonization of their individual marketing activities. It is confirmed by the average evaluation of this relation of 3.0 (on a 1 to 5 scale) and the standard deviation of 1.38. More detailed data on subjects' evaluation regarding the quality of their process of marketing planning and their marketing plans are given in Table 1. By observing the average situation for all the subjects, a general conclusion can be reached that the existing process of marketing planning does not significantly allow the management of trading companies to identify unexpected events in advance (the average grade is 2.83 and the standard deviation is 1.3). These are two rather illustrative determinants which show the quality of the marketing planning process and the quality of the marketing plans as the result of the process which is present in the business practice of trading companies in $\mathrm{BiH}$.

Table 1. Evaluation of the quality of the marketing planning process and marketing plans in trading companies in $\mathrm{BiH}$

\begin{tabular}{|c|c|c|c|}
\hline Ord. no. & Statements (observed features) & $\overline{\mathrm{x}}$ & $\sigma$ \\
\hline 1. & $\begin{array}{l}\text { Our approach to marketing planning assures that we get a high level of harmonization of our individual marketing } \\
\text { activities. }\end{array}$ & 3.00 & 1.38 \\
\hline 2. & Our process of marketing planning enables us to identify unexpected events in advance. & 2.83 & 1.30 \\
\hline 3. & $\begin{array}{l}\text { When we face unexpected events, our process of marketing planning decreases the risk of unreasonable actions to } \\
\text { the minimum. }\end{array}$ & 2.70 & 1.18 \\
\hline 4. & Marketing plans decreases conflicts between managers regarding the question "where the company should go." & 3.31 & 1.37 \\
\hline 5. & $\begin{array}{l}\text { Due to the marketing plan we have better communication between the organization units in the company regarding } \\
\text { the marketing-related issues. }\end{array}$ & 3.42 & 1.36 \\
\hline 6. & Our process of marketing planning forces management to think of the future systematically. & 3.33 & 1.58 \\
\hline 7. & Marketing plan allows us to successfully adapt the resources to the circumstances. & 3.82 & 1.05 \\
\hline 8. & Marketing plan gives us a useful framework for constant checks of advancement. & 3.73 & 1.02 \\
\hline 9. & On the basis of marketing planning we developed more profitable marketing strategies. & 3.22 & 1.14 \\
\hline
\end{tabular}

Legend: $\overline{\mathrm{x}}$ - average grade of the situation in one's own company by the indicated statements in the 1-5 interval (1-absolutely disagree, 5-absolutely agree); $\sigma$ - standard deviation.

Source: Author's research.

Marketing managers of trading companies think that the greatest value of their marketing plans has so far been reflected in the fact that these plans enabled them to successfully adapt the resources to the circumstances. However, if we take into consideration the fact that the average grade of the best rated aspect of the quality of marketing planning is 3.82 (the standard deviation 1.05), it is evident that the total quality of the strategic marketing planning process is not at a satisfactory level and that it cannot generate the strengthening of competitive advantages of trading companies on today's ever demanding market.

Another aspect of business activities in which marketing plans proved to be most successful for marketing managers in trading companies, can be seen in the fact that these plans give a useful framework for constant checks of progress. Also, an average grade of this aspect of the quality of marketing planning is at a relatively low level and it is 3.73 (the standard deviation 1.02).

The lowest graded aspect of the quality of the marketing planning process in trading companies in $\mathrm{BiH}$, with the average grade of 2.70 (the standard deviation of 1.18), is the absence of marketing managers' possibilities to timely perceive unexpected events and to minimize the decisions risk under such circumstances. The average grades ranging 3.22 to 3.42 were given to the remaining observed aspects of the quality of the marketing planning process in trading companies in $\mathrm{BiH}$ (possibilities to develop profitable strategies on the basis of marketing planning; then reaching consensus within the management structure regarding the question "where should the company go in terms of business"; management orientation to think of the company's future on the systematic basis; possibilities to improve the quality of communication between the organization units in the 
company related to the harmonization of certain marketing activities).

\subsection{Analysis of the Effects of the Marketing Planning Process}

Based on ten dependent variables presented in Figure 2, the quality was measured of the results (output) of the marketing planning process in trading companies. Out of the total number of the marketing managers of trading companies in $\mathrm{BiH}$ surveyed, a quarter believes that their process of marketing planning does not give appropriate results, as they think that their companies miss chances on the market. The remaining three quarters of the subjects believes that their companies do not miss chances to make profit. A significant number of the subjects $(23.33 \%)$ think that their long-term planning looks like a set (group) of meaningless numbers. Out of the total number of the subjects, $18.33 \%$ of the marketing managers believes that their marketing goals are unreasonably set, and as many as $60.0 \%$ believes that they lack practical market information. The data for all the trading companies by all dependant variables are given in Figure 2 which illustratively shows the profile of the marketing planning output.

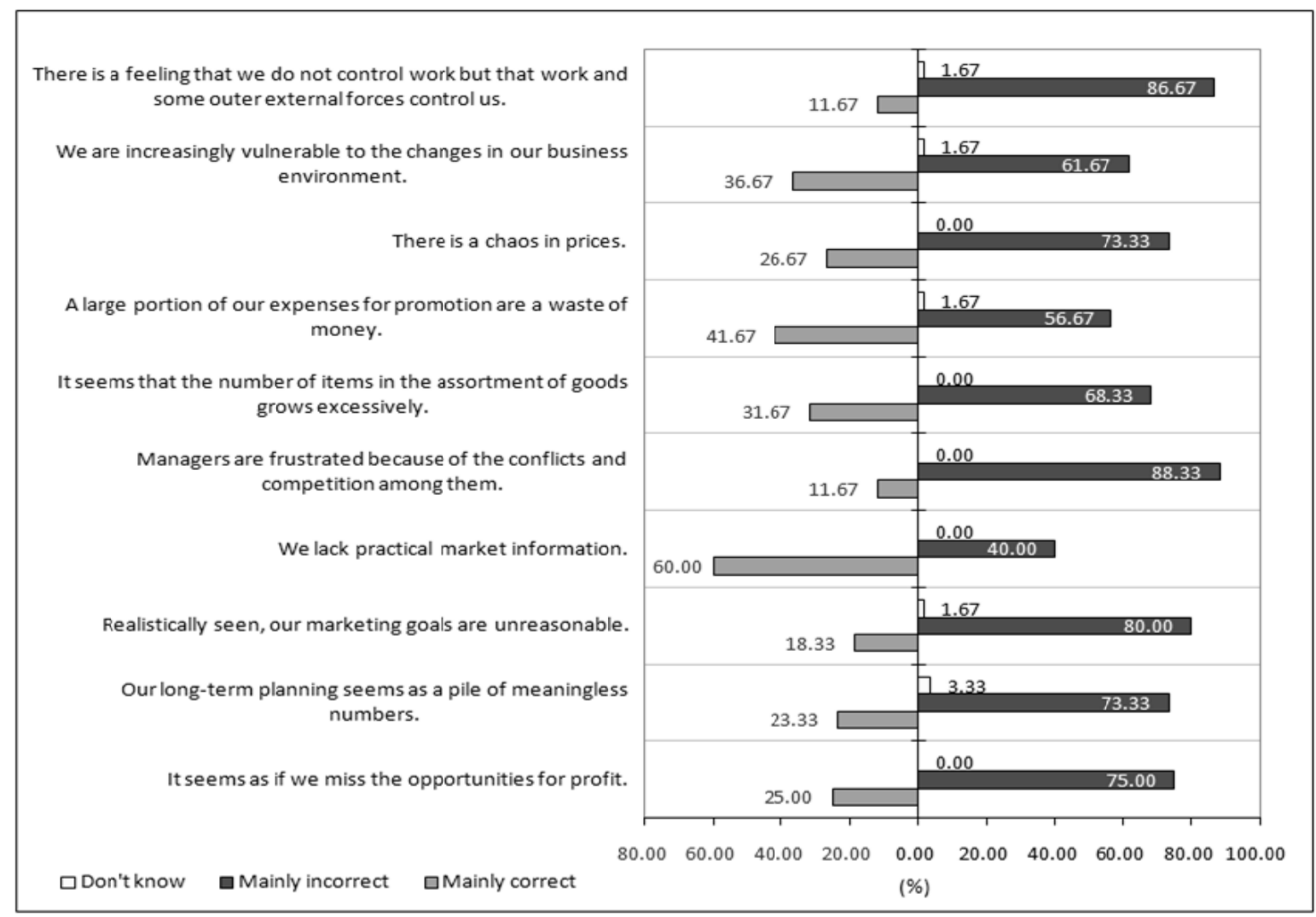

Figure 2. Evaluation of the output of the marketing planning process in trading companies in BiH (Author's research)

The right side of the figure shows the level in which marketing managers of trading companies do not have problems in planning and the scope in which the marketing planning process is good. Opposite that, the left side of the figure shows the level in which the marketing planning process shows disadvantages and downsides. Besides the lack of practical market information that is present in $60.0 \%$ of the subjects, the next large disadvantage of the results of the marketing planning process in trading companies is evident in the fact that $41.67 \%$ of them believes that a large portion of their expenditures for promotion is the wasted money. Besides that, a large disadvantage of the marketing planning process is the fact that the created marketing plans do not provide sufficient "protection" of the company against the changes in business environment, that is, timely adaption to new challenges and market demands. Indeed, one of the roles of marketing plans is to prepare the company to changes and challenges coming from the surrounding. Out of the total number of the subjects, in $36.67 \%$ of the trading companies marketing plans did not fulfill this role. In $31.67 \%$ of the trading companies the marketing planning process did not suit to the issue of efficient and effective management of selection of goods, while in $26.67 \%$ of the trading companies the role of marketing plans was not realized in term of the price policy. 


\subsection{Discriminant Analysis of the Quality of Marketing Planning in Trading Companies in Bosnia and Herzegovina}

In the following part of the paper, applying the multivariate analysis (the method of discriminant analysis), we shall establish whether there is a difference in the quality of the marketing planning process and marketing plans for the subjects that have a systematic approach and formalized strategic marketing plan (in the form of a document) and for the subjects that do not have such an approach to the marketing planning process. In this case the category variable is the possession of the strategic marketing plan as a document (categories: 0-does not possess, 1-possesses). The independent variables are the aspects of the quality of the marketing planning process and marketing plans measured on a 1 to 5 scale (Table 1).

The first important parameter in this analysis is the value of Wilks' Lambda (Wilks' $\lambda$ ), Table 2. This parameter is used for testing the hypothesis on the statistical significance of the model of discriminant analysis. Since Sig. $=0.000$, it can be concluded that the given model of discriminant analysis is statistically significant.

Table 2. Wilks' Lambda (author's calculation)

\begin{tabular}{ccccc}
\hline Test of Function(s) & Wilks' Lambda & Chi-square & df & Sig. \\
\hline 1 & .501 & 36.991 & 9 & .000 \\
\hline
\end{tabular}

Table 3 presents the value of canonical correlation. This coefficient, i.e. its square value is used for measuring the ratio of disciminant function and the category variable. Since the square of the canonical correlation in this particular case is $0.706^{2}=0.498436$, it can be established that $49.84 \%$ of variance of the dependant variable explains the discriminant model.

Table 3. Value of canonical correlation (author's calculation)

\begin{tabular}{ccccc}
\hline Function & Eigenvalue & \% of Variance & Cumulative \% & Canonical Correlation \\
\hline 1 & $.997^{\mathrm{a}}$ & 100.0 & 100.0 & .706 \\
\hline
\end{tabular}

Note: a. First 1 canonical discriminant functions were used in the analysis.

In the following table we wanted to assess the ability of the model to predict whether the management of trading companies, based on their past experience in marketing planning and the realized effects of their past marketing plans, decide to formalize their strategic marketing planning, meaning to create a document which will include the strategic marketing plan. Based on the data provided in Table 4 (see the note in the last line of the table), it is possible to calculate the quotient of guesses $(51+6) /(51+2+1+6)=0.95 \Rightarrow 95 \%$.

Table 4. Results of classification (author's calculation)

\begin{tabular}{cccccc}
\hline & & & \multicolumn{2}{c}{ Predicted Group Membership } & \multirow{2}{*}{ Total } \\
\cline { 3 - 6 } Original & Independent variable & & .00 & 1.00 & 53 \\
& Count & .00 & 51 & 2 & 7 \\
& & 1.00 & 1 & 6 & 100.0 \\
& $\%$ & .00 & 96.2 & 3.8 & 100.0 \\
\hline
\end{tabular}

Note: a. $95,0 \%$ of original grouped cases correctly classified.

It is important for further analysis to consider the data given in Table 5. Namely, the data enable us to determine the influence of certain effects (evaluation aspects) of the marketing planning process and marketing plans on the commitment of marketing managers in trading companies to create a document which will include the strategic marketing plan. Based on the values given in the Sig. column, which are less than 0.05 for all independent variables, it can be concluded that the null hypothesis is rejected, meaning that there is no equality of the average value for each independent variable for the subjects who create the document which includes the strategic marketing plan and the subjects who do not do that. This actually means that there is a statistically significant difference between the companies that have the formalized process of strategic marketing planning and those that do not have it in all the observed aspects of the evaluation of the quality of marketing plans. 
Table 5. Equality test of the average values of the observed variables for two groups of subjects (author's calculation)

\begin{tabular}{|c|c|c|c|c|c|c|}
\hline & Variables & $\begin{array}{l}\text { Wilks' } \\
\text { Lambda }\end{array}$ & $\mathrm{F}$ & df1 & $\mathrm{df} 2$ & Sig. \\
\hline Depend_1 & $\begin{array}{l}\text { Our approach to marketing planning assures that we get a high level of } \\
\text { harmonization of our individual marketing activities. }\end{array}$ & .717 & 22.895 & 1 & 58 & .000 \\
\hline Depend_2 & $\begin{array}{l}\text { Our process of marketing planning enables us to identify unexpected events in } \\
\text { advance. }\end{array}$ & .677 & 27.735 & 1 & 58 & .000 \\
\hline Depend_3 & $\begin{array}{l}\text { When we face unexpected events, our process of marketing planning decreases the } \\
\text { risk of unreasonable actions to the minimum. }\end{array}$ & .759 & 18.440 & 1 & 58 & .000 \\
\hline Depend_4 & $\begin{array}{l}\text { Marketing plans decreases conflicts between managers regarding the question } \\
\text { "where the company should go." }\end{array}$ & .802 & 14.294 & 1 & 58 & .000 \\
\hline Depend_5 & $\begin{array}{l}\text { Due to the marketing plan we have better communication between the organization } \\
\text { units in the company regarding the marketing-related issues. }\end{array}$ & .817 & 12.988 & 1 & 58 & .001 \\
\hline Depend_6 & $\begin{array}{l}\text { Our process of marketing planning forces management to think of the future } \\
\text { systematically. }\end{array}$ & .851 & 10.188 & 1 & 58 & .002 \\
\hline Depend_7 & Marketing plan allows us to successfully adapt the resources to the circumstances. & .829 & 11.944 & 1 & 58 & .001 \\
\hline Depend_8 & Marketing plan gives us a useful framework for constant checks of advancement. & .794 & 15.044 & 1 & 58 & .000 \\
\hline Depend_9 & $\begin{array}{l}\text { On the basis of marketing planning we developed more profitable marketing } \\
\text { strategies. }\end{array}$ & .669 & 28.672 & 1 & 58 & .000 \\
\hline
\end{tabular}

Table 6 shows the values of structural correlation (discriminant intensity). The values of discriminant intensities for all independent variables are higher that 0.3 , which means that all independent variables have the practical value, meaning that they have the influence on the decision of marketing managers in trading companies regarding the formalization of the strategic marketing planning process. In literature, the value 0.3 is taken as the empirical limit for respecting the mentioned influence.

Table 6. Structural matrix (author's calculation)

\begin{tabular}{lll}
\hline & \multicolumn{1}{c}{ Variables } & Function 1 \\
\hline $\begin{array}{ll}\text { Depend_9 } \\
\text { Depend_2 }\end{array}$ & On the basis of marketing planning we developed more profitable marketing strategies. & .704 \\
Depend_1 & Our approach to marketing planning assures that we get a high level of harmonization of our individual & .693 \\
& marketing activities. & .629 \\
Depend_3 & When we face unexpected events, our process of marketing planning decreases the risk of unreasonable actions & .565 \\
& to the minimum. & .510 \\
Depend_8 & Marketing plan gives us a useful framework for constant checks of advancement. \\
Depend_4 & Marketing plans decreases conflicts between managers regarding the question "where the company should go." & .497 \\
Depend_5 & Due to the marketing plan we have better communication between the organization units in the company & .474 \\
& regarding the marketing-related issues. & .455 \\
Depend_7 & Marketing plan allows us to successfully adapt the resources to the circumstances. \\
Depend_6 & Our process of marketing planning forces management to think of the future systematically. & .420 \\
\hline
\end{tabular}

Pooled within-groups correlations between discriminating variables and standardized canonical discriminant functions.

Variables ordered by absolute size of correlation within function;

Depend-DEPENDANT VARIABLE

The aspects of the evaluation of the quality of the marketing planning process and quality of marketing plans whose discriminant intensities are ranged in the interval form 0.3 to 0.6 are considered to represent moderate predictors. If the value is higher than 0.6 , it is considered that the given variable represents a strong predictor. In the specific case, based on the value of discriminant intensities, it can be concluded that the profitability of certain marketing strategies and possibility to identify unexpected events in advance are the two elements which have the largest influence on the readiness of marketing managers in trading companies to formalize their process of strategic marketing planning. 


\section{Conclusion}

In modern business conditions, marketing managers, if they want to improve their business performances, need to establish the process of strategic marketing planning on formalized and systematic bases. This is confirmed by the results of this research into the business practice of trading companies in $\mathrm{BiH}$.

Namely, the research results show that over $60.0 \%$ of the trading companies in Bosnia and Herzegovina have neither clearly determined/identified marketing goals of business nor are they harmonized with their total business goals. It is completely understandable then that in these companies we have not identified the clear strategy for achieving business goals. Besides that, $83.33 \%$ of the trading companies do not have a back-up plan in case the set marketing goals of business are not realized. Also, $72.88 \%$ of the trading companies do not have an employee who is specifically in charge of collecting and analyzing the data on strengths and weaknesses that exist within the company, as well as the data on the opportunities and threats in the environment. All the mentioned indicators, among others, represent the basic elements of the high-quality process of creating a marketing strategy. However, they are poorly present in the business practice of the trading companies observed. In this was the first research hypothesis has been confirmed, that is, the strategic marketing planning process in business practice of trading companies in $\mathrm{BiH}$ is not based on systematic and strategic principles.

On the other hand, it is understandable that such process of strategic marketing planning generates numerous problems that, among others, reflect in the lack of practical market information, which has been registered in $60.0 \%$ of trading companies. Besides, a large portion of expenses for promotion for $41.67 \%$ of the trading companies is actually the waste of money. For $36.37 \%$ of the trading companies it has been established that they are less able to successfully meet the challenges which are the results of the environment changes.

By the discriminant analysis the second research hypothesis has been confirmed. Namely, it has been established that there is a statistically significant difference between the companies which have the formalized process of strategic marketing planning and those which do not have it by all nine observed aspects of the evaluation of the quality of marketing plans. The possibility to improve business profitability, then possibility for timely identification of unexpected activities, and possibility to ensure a high level of harmonization of individual marketing activities with the total marketing goals are the key features that significantly determine the difference in the quality of the strategic marketing planning process between the trading companies with the formalized and systematic approach to creating marketing plans and the trading companies without such approach.

\section{References}

Baker, M. J. (2000). Marketing Strategy and Management. London, UK: MacMillan Press Ltd.

Becker, U. J., Greve, G., \& Albers, S. (2010). How to Prevent CRM Implementations from Failing. GfK Marketing Intelligence Review, 2(2), 34-41.

Begtić, R. (1997). Upravljanje poslovnim marketingom. Tuzla: Ekonomski fakultet Univerziteta u Tuzli.

Berry, L. L. (1995). Relationship marketing of Services: Growing Interest, Emerging Perspectives. Journal of the Academy Marketing Science, 23(4), 236-245. http://dx.doi.org/10.1177/009207039502300402

Chopra, K. (2007). Strategic Marketing: Role of Relationships, Information \& Services. Amity Business School, India. Retrieved from http://papers.ssrn.com/sol3/papers.cfm?abstract_id=761464

Colborn, J. (2006). Search Marketing Strategies. Great Britain: Elsevier.

Dekimpe, M. G., \& Hanssens, D. M. (2007). Persistence Modeling for Assessing Marketing Strategy Performance. Erasmus Research Institute of Management (ERIM). Retrieved from http://papers.ssrn.com/sol3/papers.cfm?abstract_id $=474728$

Doyle, P. (2008). Value-Based Marketing: Marketing Strategies for Corporate Growth and Shareholder Value. New Jersey: John Wiley \& Sons Ltd.

Hollensen, S. (2003). Marketing Management: Relations Approach. UK: Pearson Education Limited.

Kotler, P. (2001). Upravljanje marketingom. Zagreb: Mate.

Larson, J. S., Bradlow, E. T., \& Fader, P. S. (2006). How do shoppers really shop? ECR Journal, 6(1), 55-63.

Lovreta, S., \& Petković, G. (2010). Trgovinski marketing. Beograd: Centar za izdavačku djelatnost Ekonomskog fakulteta u Beogradu.

McDonald, M. (2004). Marketinški planovi: Kako ih praviti, kako ih koristiti. Zagreb: Masmedia.

Myers, H., \& Alexander, N. (2007). The role of retail internationalization in establishment of a European retail 
structure. International Journal of Retail \& Distribution Management, 35(1), 6-19. http://dx.doi.org/10.1108/09590550710722314

O’Sullivan, D., \& Abela, V. A. (2010). Marketing Performance Measurement and Its Effects on Marketing's Stature and Firm Success. GfK Marketing Intelligence Review, 2(2), 42-49.

Omar, O. (1999). Retail Marketing. London: Prentice Hall.

Paley, N. (2005). The Manager's Guide to Competitive Marketing Strategies. NH, USA: Books Network International Inc.

Peppers, D., Rogers, M., \& Dorf, B. (1999). Is Your Company Ready for One-to-One Marketing? Harvard Business Review, 77(1), 151-160.

Renko, N. (2005). Strategije marketinga. Zagreb: Naklada Ljevak.

Walker, O. C., Boyd, H. H., \& Larreche, J. C. (1996). Marketing Strategy, Planning and Implementation. New York: Richard D. Irwin. 